\title{
Conditions necessary for the sustainability of an emerging area: the importance of banking and financial regional criteria
}

\author{
Céline Gimet
}

\begin{abstract}
The last financial crises have revealed the vulnerability of many emerging countries. Yet, within an economically integrated area, some groups of countries have been spared the disastrous consequences of these crises. The purpose of this article is to underline the similarities between these countries in order to draw up a set of regional criteria that would protect an area against speculative attacks. Using a probit analysis, we show that the convergence of some banking and financial indicators towards reference levels guarantees the confidence of international lenders, which in turn limits financial contagion. A narrow margin between the amount of external debt, in particular the short term debt of the country and a reference level constitutes a protection against the risk of illiquidity. Similarly, a low domestic credit in comparison with the international reserves of the economy is also an indicator of the sustainability of an area for international lenders. It is these factors that have ensured the stock exchange stability that some emerging areas have enjoyed during the different crisis episodes.
\end{abstract}

Keywords: Economic and Financial Integration, Emerging Markets, Fundamental Contagion, Probit Analysis, Regional Criteria.

JEL Classification : F02, F34, F41, G15. 


\section{Introduction}

Several financial crises occurred in emerging markets during the nineties. These crises forced them to abandon their fixed or intermediate exchange rate and let their currency float. One of the main characteristics of these crises is their chronological and geographic concentration: each of them first spread in the region where it was born, crossed the borders and sometimes infected more distant regions. Kaminsky, Reinhart and Vegh (2003) distinguish two types of dynamics: on the one hand, the "Fast and Furious" episodes of contagion, which followed the Mexican (1994), Thai (1997) and Russian (1998) crises and, on the other hand, those with limited external consequences (Brazil (1999), Turkey (2001), Argentina (2001)). The propagation channels of these crises can be real or financial and depend on the relations between the country where the crisis was born and the infected country. There is a great deal of economic literature on this subject. The main problem met concerns the definition of contagion depending on whether it is the fundamental or the purely psychological aspect (Masson (1998)) that is being considered. This study deals with fundamental contagion (Dornbusch Park and Claessens (2000)), with reference to non-crisis-contingent theories (Forbes and Rigobon (2000)) because it explains the regional character of these crises. Consequently, different transmission channels resulting from the interdependence among markets have to be considered: the real channel through trade links between countries (Glick and Rose (1999)), the financial channel which includes both banking exchanges between the countries, taking into consideration the role of the common creditor (Van Rijckeghem and Weder (1999), Caramazza Ricci Salgado (2000)), and the variations in financial assets following portfolio reallocations by international investors in countries with the same macroeconomic profile as the first country hit by crisis (Folkerts-Landau and Garber (1998), Schinasi and Smith (1999), Calvo (1999), Kaminsky and Reinhart (1999), Kodres and Pritsker (2002)). 
Some of the countries that have experienced contagion spillovers have simultaneously engaged in processes of regional integration, for example in Latin America (Mercosur), Asia (Asean) and Eastern Europe (Cefta). Today these areas have reached the third stage of the Balassa (1961) classification: the common market. Therefore, it is extremely interesting to analyse the possible interactions between these two phenomena in order to determine a set of regional criteria that could constitute collective protection against crisis.

Many studies have tried to explain the spread of crises across countries by regressive models like probit/logit. They have considered real and financial bilateral relation between the first country hit by the crisis and every infected country, and other control variables - considered only during the year preceding the crisis - in order to determine the macroeconomic similarities between countries hit by this crisis (Eichengreen, Rose and Wyplosz (1996), Glick and Rose (1999), Van Rijckeghem and Weder (1999)). In most cases, macroeconomic similarities seem to have played a minor part in crisis propagation. To improve these analyses, we are going, on the one hand, to compare the evolution of the indicators over the four years preceding the crisis from a regional point of view and, on the other hand, to concentrate on the role played by the banking and financial structures of the countries and their illiquidity risk in the spread of crisis. It is clear that real contagion phenomena are difficult to avoid. Nevertheless, the financial and banking sectors offer the possibility of using regional protection mechanisms against crises.

We study the contagion phenomenon in each commercial area during the different crises since the Mexican episode. Firstly, national indicators are used. Secondly, the problem is considered on a regional level. We conclude that if some countries were not infected, it is 
because they were aligned and because their main aggregates converge to a level, which international banks and investors take as a reference.

A second section deals with the choice of the criteria used in our analysis and with the presentation of the method. In a third section the results obtained are analysed before concluding.

\section{An empirical study}

\subsection{Probit analysis}

A probit analysis has been selected. This method seems to be well suited to determining the influence of independent variables on a dependent variable $^{l}$ :

$y_{i}^{*}=\beta^{\prime} x_{i}+\varepsilon_{i}, i=1 \ldots N$,

$y_{i}=1$ if $y_{i}^{*}>0,0$ if not and $\varepsilon_{i} \sim N(0,1)$

$y *$ represents the unobservable variable, $y$ the observed one that takes the value 1 or $0, x$ is the vector of the explanatory variables and $\beta$ ' the vector of the coefficients to be estimated.

The probability $y_{i}=1$ can be expressed as the function:

$$
P\left(y_{i}=1\right)=P\left(y_{i}^{*}>0\right)=F\left(\beta^{\prime} x_{\mathrm{i}}\right)
$$

where $F$ is the standard normal cumulative distribution function. The model is estimated using the maximum likelihood method.

Our analysis is based on a sample of 18 countries. All of them come from three distinct emerging and economically integrated areas: 6 Mercosur countries ${ }^{2}, 6$ Asian countries ${ }^{3}$ and 6

\footnotetext{
${ }^{1}$ Specific effects have not been taken into consideration because the hypothesis that enables us to consider the random effect probit model is not respected (the rho $=0$ hypothesis is not rejected).

${ }^{2}$ Argentina, Bolivia, Brazil, Chile, Paraguay and Uruguay.

${ }^{3}$ Indonesia, Korea, Malaysia, the Philippines, Singapore and Thailand.
} 
Cefta countries ${ }^{4}$. Different periods are considered, depending on the four crisis stages that we have chosen. These are the four years preceding a crisis (with monthly data), that is to say: from 1990M12 to $1994 \mathrm{M} 12$, and from 1997M12 to 2001M12 for Latin America, from 1993M7 to 1997M7 for Asia and finally from 1997M2 to 2001M2 for Eastern Europe.

Our first series of tests considers the level of each country's macroeconomic, financial and banking variable during the year preceding each period of crisis. The purpose is twofold: first, to identify the main channels of contagion that played a part during the period considered, afterwards, to see if similarities exist between the countries hit by contagion.

We then carry out new tests in order to define a group of regional criteria that protect the area against contagion. At a regional level, the countries are grouped into two distinct blocks.

Finally, all the data are pooled together in a single test in order to underline the most significant characteristics of the region spared by contagion.

\subsection{The choice of criteria}

\section{The dependent variable}

Firstly, it is necessary to distinguish, for each episode of crisis, the countries that have experienced the crisis and those that have not. We use a crisis index based on that proposed by Kaminsky and Reinhart (1996), (1999):

$$
I=\% \Delta e-\frac{\sigma_{e}}{\sigma_{R}} \% \Delta R
$$

The two variables chosen are the rate of change in percent of the real exchange rate $(\% \Delta e)$, in order to avoid the inflation problem, and the rate of change in the amount of international reserves $(\% \Delta R)$ in the economy. $\sigma_{\mathrm{e}}$ and $\sigma_{\mathrm{R}}$ represent the standard deviation of these variables.

\footnotetext{
${ }^{4}$ Bulgaria, Czech Republic, Hungary, Poland, Slovakia and Slovenia.
} 
They are based on data covering the three years preceding the crisis. The index taken into account is therefore a weighted average of the two rates of change, which have equal volatility. We consider that the country suffers from a crisis when the index is superior or equal to three standard deviations above the mean. This binary variable, which takes the value 1 (if the country is hit by crisis) or 0 (if not), corresponds to the dependent variable of the probit model. It is called contagion. The results are presented in table 1, table 2 and table 3 divided into period of crisis and region.

Table1 List of Mercosur countries hit by Latin American crises

Table 2 List of Asean countries hit by the Thai crisis

Table 3 List of Cefta countries hit by the Turkish crisis

This index of speculative pressure has been chosen because of the availability of data. However, when the standard deviation of stock market and bond market indicators ${ }^{5}$ are considered, we notice a peak in volatility in the countries identified previously as 1 in the same period (appendix A). Therefore results are similar whatever definition of crisis is used. The strength of the contagion phenomenon differs in each crisis episode. Whereas the Thai crisis (1997) had harmful effects on all the countries of the region, the Turkish crisis (2001) did not spread abroad ${ }^{6}$. As for Latin America, the crises only affected certain countries in the $\operatorname{area}^{7}$. On this point, our results are close to those of Kaminsky, Reinhart and Vegh (2003).

\footnotetext{
${ }^{5}$ These indicators correspond respectively to MSCI price index in US Dollars and to JPM EMBI global returns in US Dollars.

${ }^{6}$ It can be noticed that on the bond market the effects of the Thai crisis on the Asian countries are observed several month later.

${ }^{7}$ It can be noticed that Brazil was particularly vulnerable to the Thai crisis in 1997. This was at the origin of the devaluation of the Real in January 1999. However, as own study is limited to a regional analysis, Brazil is not taken into account in the sample of Asian countries considered before the Thai crisis.
} 


\section{Transmission channels}

For each period of instability, we determine which of the three fundamental channels played a role in the spread of the crisis. At the end of these tests, the results are compared with the ones determined in previous studies.

As for the commercial channel, the study is based on a global trade index similar to that of Glick and Rose (1999). This first variable is Trade. The amount of bilateral trade between the first country hit by the crisis and each country in the same area is considered. The first country in each episode of contagion has been determined by the crisis index: Mexico in December 1994, Thailand in July 1997, Turkey in February 2001 and Argentina in December 2001. The importance of bilateral trade between the countries is measured by calculating the weight of exports and imports between the first country and each of its trade partners compared to the first country's total of exports and imports.

Secondly, we assess the importance of the common creditor in the transmission of the crisis for the different episodes of contagion. This second variable is Comcred. In the case of Mexico, Argentina and other Latin American countries, the principal creditor is the United States. Japan is the main lender for Thailand and the Asian countries and Western European banks are the first lenders for Turkey and Eastern European countries. The financial market links between the first country's banks and its principal international creditor, and between each country of the area and the same creditor are compared in order to see if banking loans cause contagion. We use Van Rijckeghem and Weder's (1999), (2000, pp.10-11) method which consists in measuring, on the one hand, the share in total borrowing of each debtor country compared to the loans of the first country from the same lender and, on the other hand, the importance of each country compared to that of the first country in the total credit of 
this bank. Thus, we have an indicator of the extent to which countries in the same area compete for funding from the same international bank.

Thirdly, the purpose is to shed light on the role of international investors in financial markets during periods of crisis. In order to create a regional indicator we follow the postulate of Folkerts-Landau and Garber (1998), Schinasi and Smith (1999), Calvo (1999), Kaminsky and Reinhart (1999) Kodres and Pritsker (2002), who assert that when a crisis occurs in an emerging country, international investors reallocate their portfolio of assets to reduce their risks. In order to curb the loss of capital, investors sell their assets on markets likely to be affected by the crisis, that is to say the markets that fluctuate like the first country hit by the crisis (Calvo and Reinhart (1998)).

First, the stock exchange volatility of each country is measured with regard to the standard deviation of their stock exchange index during the period preceding the crisis ${ }^{8}$. If the countries hit by the crisis are those that experience a lot of financial instability, we can deduce that financial contagion has played a role during the crisis episode considered $(\mathrm{Vol})$.

In order to underline a regional aspect of this phenomenon, we compare the volatility of the financial market in the countries that have been hit by the crisis with those that have been spared. Then, a composite indicator of emerging markets' stock exchanges for each block of countries is created and the standard deviation enabling us to show the volatility of each one is calculated (Vol_rg). The stock exchange indexes are the same as those previously mentioned. They are all calculated using the same method, which considers an aggregate market capitalization of $70-80 \%$ of the total capitalization of all domestic shares. The data of each period are linked by the Paasche chain method, and the period of reference is December 1994. To work out indicators for each group of countries and each period of crisis, we

\footnotetext{
${ }^{8}$ The stock exchange index used is drawn from the Standard and Poor database concerning emerging markets and corresponds to the S\&P/IFCG index.
} 
calculate the average of these indicators, weighted by the financial importance ${ }^{9}$ of the country in the block to which it belongs. Therefore, important fluctuations in the regions hit by the crisis show the role of international investors' behaviour in the spread of crisis $^{10}$.

\section{From national to regional criteria.}

Firstly, for each crisis episode, we determine the main weaknesses responsible for the vulnerability of each country to financial contagion. Then, we underline some similarities concerning the macroeconomic and financial profile of the countries hit by crisis in the same area during the year preceding the crisis. The dependent variable takes the value 1 or 0 whether the country has undergone the crisis or not ${ }^{11}$.

Secondly, each region analysed is divided into two blocks: one made up of countries spared by the crisis (block 0 ), the other of countries affected by contagion (block 1). The distribution between the two blocks is stable. The purpose is to show the evolution, during the four years before the crisis, of the margin between the situation of countries that have not been hit by crisis and a reference level. A cross-section convergence test, sigma-convergence, is selected. This seems to be the most appropriate method for showing both the convergence of indicators between different countries and their evolution towards an exogenous norm (Fuss (1999)). Sigma-convergence is based on an indicator of dispersion. When there is convergence, the indicator decreases.

$$
\underset{i}{\operatorname{Var}}(X)=\sum_{i=1}^{I} \eta_{i}\left(X_{i, t}-\bar{X}_{t}\right)^{2} \text { with } t=1, \ldots, 49
$$

\footnotetext{
${ }^{9}$ This indication is given by Standard and Poor.

${ }^{10}$ It is to be noticed that our work is limited by the availability of data concerning stock exchange markets, especially in the Mercosur for Paraguay and Uruguay. Moreover, the periodicity of the data (monthly reports) provides a synthetic indicator open to criticism.

${ }^{11}$ It is to be noticed that Brazil is considered as belonging to block 1 during the period 1997M12, 1999M12 then to block 0 during the period 2000M1, 2001M12 because of the crisis of the Real in January 1999. It is an exception, as it is the only country that has been part of both blocks during a same period.
} 
$\eta_{i}$ is the weighted coefficient attributed to country $i$ according to its importance in the cluster 0 or $1^{12} . X_{i, t}-\bar{X}_{t}$ is the differential observed between each country and the reference ${ }^{13}$. The standard deviation corresponds to the square root of the variance. These regional variables are marked_reg in table 4.

For each indicator the reference chosen is the macroeconomic and financial situation of the United States, Japan, and Western Europe, weighted by their importance as a common creditor in each area during each period. Our choice is justified by the fact that emerging countries are strongly dependent on their creditors and therefore on macroeconomic and financial fluctuations of the latter. Moreover an indicator that fluctuates according to international events is more appropriate than a fixed standard.

We select 9 criteria presented in table 4. The sign in brackets corresponds to the expected relation between contagion probability and each independent variable. It is to be noticed that in our study a low level of the budgetary and the current account national indicators reveals a large deficit. Moreover, there is no collinearity between each variable but, because of the proximity of the external debt and illiquidity risk indicators, they are considered in two distinct regressions so as to avoid this collinearity problem.

Table 4. List of explanatory variables

\footnotetext{
12 It corresponds to the weight of the Gross domestic product of the country compared to the total Gross domestic product of the block.

${ }^{13}$ When the level of the domestic variable is higher than the level of the reference, the gap between the two variables is regarded as null.
} 


\section{The results}

Even if the results based on national and regional criteria are close, some differences do exist. It can be noticed in some cases that an indicator is significant at the national level but not at the regional level. We can conclude that it is not the level of the indicator which influences the dependent variable, but the margin between the level of the variable and a level of reference beyond which the situation of the country or the region is judged unsustainable. So it is important to take into consideration the fact that a common reference exists for each indicator. Below this reference the risk of loss in international lenders' confidence increases. In an economically integrated region where a crisis occurs, the difference between the countries that are hit by financial contagion and the ones that are protected from the crisis depends on their propensity to withdraw from, or to converge towards the reference level used by international lenders to evaluate the sustainability of a country or an area.

Moreover, it can be noticed that the regional indicator is more precise because it takes into account the economic weight of the country within a region, which reflects its relative importance for international lenders.

Table 5. Results of the probit analysis with national indicators

Table 6. Results of the probit analysis with regional indicators

Our study based on the Mexican crisis period suffers from the lack of stock exchange data (Table 5 and 6). However, the results reveal considerable sensitivity of countries to real contagion through bilateral trade. Our results are close to those of Glick and Rose (1998). Moreover, as emphasised by these authors, there is no significant influence from financial and 
macroeconomic variables. Indeed, our analysis does not reveal an increased deterioration of certain indicators in the blocks of countries affected by the Mexican crisis. The only difference between the two blocks is the gap between the interest rate of the countries hit by crisis and a reference level. This can be explained by the fact that interest rates were very high in Brazil at the beginning of the last decade in order to limit inflation. Nevertheless, there was no financial contagion through the channel of the common creditor. This result can be justified by the fact that no significant disparities in financial and banking indicators appear. Van Rijckeghem and Weder (2000) explain the limited influence of the common creditor during the Mexican crisis by the low impact of the crisis on bank lenders. Indeed, financial liberalisation did not influence the spread of the crisis because the countries most hit were those least open to foreign capital. This situation can be explained by the fact that Chile, which belongs to block 0 , opened its capital account before the other countries of the area which at the beginning of the nineties were just starting their liberalisation.

Finally, the most economically integrated countries are the most vulnerable to the spread of the crisis. Indeed, trade between Argentina and Brazil - which belong to block 1 - is very developed because of their economic weight in the area and because they have had commercial agreements since the seventies.

During the period preceding the Argentina crisis the countries that had been hit by the consequences of this shock suffered from a lot of financial instability aggravated by the Brazilian crisis (table 5 and 6). Among these were Paraguay and Brazil (at the beginning of the period). They experienced had a very high interest rate, which increased budgetary deficit. Moreover, their external debt, in particular short-term debt, worsened. However, their influence is relative because of the light weight of Paraguay in comparison to Brazil and Argentina within the block. In addition, when the crisis occurred, these countries, which had 
suffered from a lack in international creditors' confidence, saw the share of foreign capital decrease significantly, and consequently greater volatility of their stock exchange. Besides, during this period Argentina, which had been weakened by the Brazilian crisis, suffered from important pressure on its exchange rate. Therefore, in order to maintain the currency board, it had to increase its foreign debt. Its trade partners' devaluation contributed to an aggravation of the situation. Finally, after the disturbances that destabilized the area Uruguay, with the help of the International Monetary Fund and the World Bank, tried to maintain its crawling peg, which generated an important increase in its external debt and its budgetary deficit.

Thus, this phenomenon caused a great deal of financial contagion. Our national and regional indicators show a lot of financial fragility which is at the origin of the loss of international banks' and investors' confidence as shown by significant financial contagion indicators. A high budgetary deficit in these countries aggravated by a lack of liquidity and a substantial debt reveals a risk of unsustainability. This important unbalance and significant financial volatility seem to be the main indicators that international lenders use to assess the risk of crisis in the area. Indeed, the block of countries that were spared by the crisis had taken advantage of a convergence of their financial and banking indicators towards a sustainable level for international investors which began after the Brazilian crisis (appendix C). A low influence of the financial liberalisation indicator can be noticed. This is explained by the fact that the countries most hit by the crisis were not those whose assets and liabilities stocks were the highest because, after the Brazilian crisis, the area suffered from considerable capital outflows.

Finally, there was real contagion because of the weight of trade between Argentina and Brazil before the Real devaluation. This phenomenon does not seem to be linked to greater regional economic integration between block 0 countries. Our results concerning this indicator vary. Therefore, we cannot draw any conclusion regarding the importance of this variable. 
In order to underline the weaknesses of the Southeast Asian countries before the Thai crisis, we have chosen to compare this block of countries to the group made up of the East European countries that were spared the harmful consequences of the Turkish crisis (table 5 and 6). Our results reveal contagion generated by bilateral trade, by the common creditor and by stock exchange volatility at the same time. So our conclusions are in agreement with those of Glick and Rose (1998) concerning the importance of the international trade channel, with those of Van Rijckeghem and Weder (2000) on the same point and also concerning the common creditor, and those of Dornbusch, Park and Claessens (2000). According to the latter, a lot of stock exchange volatility represents a risk for international investors, which generated financial contagion during the Asian crisis. The spread of the crisis was caused by the deterioration of the banking and financial situations of countries of the area although the macroeconomic environment was sustainable. Indeed, in the period preceding the crisis, Southeast Asian countries had low budgetary and current deficits. Moreover, the interest rates of these countries were low in comparison to the level of reference and to the level of the East European countries that hoped to join the European Union.

On the other hand, the situation of the banking and financial sectors in the Asian countries worsened during the same period ${ }^{14}$. The large decrease in banking liquidities reflects a credit "boom". Short-term debt rose, increasing the total amount of external debt. The consequence was a decline in international creditors' confidence which was at the origin of higher stock exchange volatility. The level of financial integration in Asian countries was very high. This early capital account openness was at the origin of excessive risk-taking which is shown by the banking and financial indicators' deterioration during the four years preceding the Thai crisis.

\footnotetext{
${ }^{14}$ It can be noticed that the over large margin concerning the indicator credrisk_rg between the level of the variable of block 1 compared to block 0 (the dispersion of block 1 is greater than those of block 0 ) prevents us integrating this indicator in our regional probit analysis.
} 
Finally, we cannot draw any conclusion regarding the link between economic integration and contagion. Indeed, the two areas seem to have the same level of regional integration.

In order to have a global vision of emerging areas spared by financial crisis, the indicators corresponding to each crisis episode are pooled (table 5 and 6). It can be noticed that the study based on national criteria and that based on regional criteria often display similar results regarding the main weaknesses that create financial contagion. With respect to the regional criteria - because of their precision and their explanatory power - we can conclude that it is not the deterioration of macroeconomic indicators that generates financial contagion but the weakness of the financial and banking sectors. Indeed, the most vulnerable areas have moderate current and budgetary deficits compared to the industrial countries that are taken as a reference. Moreover, the margin between inflation and interest rates in these countries and the reference level is slight. Consequently our results converge with those of empirical literature which show that macroeconomic similarities play a minor role in the spread of crisis. On the other hand, we can conclude that financial and banking fragility creates financial contagion. Countries are vulnerable to the international lenders' opinion when the illiquidity risk of their banking sector is high and their external debt, particularly their shortterm debt, is heavy. This situation can be explained by the fact that in many emerging countries financial liberalisation was too rapid and not sufficiently controlled to limit risktaking behaviour. It gave rise to a weakening of the countries banking and financial institutions which were not ready to receive such a large amount of foreign capital.

Even if the commercial channel is significant in the spread of crisis, the respect of certain regional criteria would guarantee the protection of emerging areas against the harmful consequences of these crises. Besides, we have seen that it is not the most economically integrated countries which are the most affected by contagion. This leads us to conclude that 
even if there is a contagion effect through bilateral trade between the first country and its main partners, the latter do not reproduce this effect.

\section{Conclusion}

We cannot ignore the fact that the spread of financial crisis through bilateral trade between the first country hit by the crisis and its main commercial partners exists, and that it is difficult to contain. However, protection against financial contagion at a regional level is conceivable. The purpose of our study is to shed light on a group of regional criteria whose respect would guarantee the stability of emerging areas, especially during periods of crisis. The comparison of the results of the two analyses with national and regional criteria enables us to emphasise the need to take into account financial and banking regional indicators.

Indeed, convergence of external debt to a reference level - partly due to a limited short-term debt compared to the amount of international reserves in the economy - indicates that the country's financial sector is sustainable. Moreover a use of domestic credit, which does not exceed the amount of available liquidities, is necessary for the good health of the banking sector. These criteria guarantee international lenders' confidence thereby limiting the volatility of the stock exchange and thus financial contagion.

Finally, our results do not allow us to assimilate contagion phenomenon and regionalism. Therefore, rather than economic integration being mainly responsible for the spread of crisis, it is the lack of convergence of banking and financial indicators between countries towards a stable reference level that prevents the sustainability of the area.

\section{Acknowledgements}

I would like to thank the referees for their constructive comments and D. Pope, J. Barrier, F. Berni for their help in the translation of this article into English. 


\section{References}

Balassa, B., 1961. The Theory of Economic Integration. Irwin, Homewood, Illinois.

Calvo, G., 1999. Contagion in emerging markets: when Wall Street in a carrier. Working Paper, University of Maryland.

Calvo, S., Reinhart, C., 1996. Capital flows to Latin America: is there evidence of contagion effects?. World Bank Policy Research Working Paper 1619.

Caramazza, F., Ricci, L.A., Salgado, R., 2000. Trade financial contagion in currency crises. IMF Working Papers 00/55.

Chang, R., Velasco, A., 2000. Banks, debt maturity and financial crises. Journal of Economics Theory 51, june.

Chang, R., Velasco, A., 2001. A model of financial crisis in emerging markets. The Quarterly Journal of Economics 116.

Corsetti, G., Pesenti, P., Roubini, N., 1998. What caused the East Asian currency and financial crisis? Part 1. A macroeconomic overview. NBER Working Paper 6833.

Corsetti, G., Pesenti, P., Roubini, N., 1999. Paper tigers? A model of the Asian crisis. European Economic Review 43(7), 1211-36.

Dornbusch, R., Park, Y.C., Claessens, S., 2000. Contagion: understanding how it spreads. World Bank Research Observer, Oxford University Press 15(2), 177-97.

Edwards, S., 2000. Interest rates, contagion and capital controls. NBER Working Papers 7801.

Eichengreen, B., Rose, A.K., Wyplosz, C., 1996. Contagious currency crises. CEPR Discussion Papers 1453.

Forbes, K., Rigobon, R., 2000. Measuring Contagion: Conceptual and Empirical Issues. In Claessens, J. and K. Forbes, K. (Eds), International Financial Contagion. Boston MA: Kluwer Academic Publishers.

Folkerts-Landau, D., Garber, P., 1998. Capital flows from emerging markets in a closing environment. Global Emerging Markets 1(3).

Frankel, J. A., 1996. The world over the next twenty-five years: global trade liberalization, and the relative growth of different regions. Center for International and Development Economics Research Working Papers C96-061.

Furman, J., Stiglitz, J.E., 1998. Economic crises: evidence and insights from East Asia. Brooking Papers on Economic Activity 2, 1-135.

Fuss, C., 1999. Mesures et tests de convergence: une revue de la littérature. Revue de l'OFCE 69, avril.

Glick, R., Rose, A.K., 1998. Contagion and trade: why are currency crises regional. NBER Working Papers 6806.

Ingram, J., 1969. Comment: The Optimum Currency Problem. In Mundell, R.A. and Swoboda, A. (Eds), Monetary Problems in International Economy, Chicago University Press.

Kaminsky, G.L., Reinhart, C.M., 1996. The twin crises: the causes of banking and balance-ofpayments problems. American Economic Review 89(3), 473-500. 
Kaminsky, G.L., Reinhart, C.M., 1999. On crises, contagion, and confusion. Journal of International Economics 51(1), 145-168.

Kaminsky, G.L., Reinhart, C.M., Vegh, C.A., 2003. The unholy trinity of financial contagion. Journal of Economic Perspectives, American Economic Association 17(4), 51-74.

Kindleberger, C., 1986. International public goods without international government. American Economic Review 75.

Kodres, L.E., Pritsker, M., 2002. A rational expectations model of financial contagion. The Journal of Finance 57, 769-99.

Krugman, P., 1999. Balance sheets, the transfer problem and financial crisis. International Tax and Public Finance 6, 459-472.

Lane, R.P., Milesi-Ferretti, G.M., 2006. The external wealth of nations mark II: revised and extended estimates of foreign assets and liabilities, 1970-2004. IMF Working Paper WP.06/69.

Masson, P., 1998. Contagion: monsoonal effects, spillovers and jumps between multiple equilibria. IMF Working Paper WP/98/142.

Mishkin, F., 1999. Lessons from the Asian crisis. Journal of International Money and Finance 18, 709-723.

Moreno, R., 1995. Macroeconomic behaviour during periods of speculative pressure or realignment: evidence from pacific basin economies. Federal Reserve Bank of San Francisco Review 3.

Pisani-Ferry, J., 2002. Fiscal discipline and policy coordination in the Eurozone: assessment and proposals. Proceedings of a Conference organised by The Dutch Ministry of Finance.

Schinasi, G., Smith, R., 1999. Portfolio diversification, leverage, and financial contagion. IMF Working Papers 99/136.

Van Rijckeghem, C., Weder, B.S., 1999. Sources of contagion: financial or trade. IMF Working Papers 99/146.

Van Rijckeghem, C., Weder, B.S., 2000. Spillover through banking centers - A panel data analysis. IMF Working Papers 97/59. 
Appendix A. Measures of financial crisis based on stock market and bond market volatility in the three emerging areas

Fig. 1. Stock market volatility in Latin America

Fig. 2. Stock market volatility in Eastern Europe

Fig. 3. Stock market volatility in Southeast Asia

Fig. 4. Bond market volatility in Latin America

Fig. 5. Bond market volatility in Eastern Europe

Fig. 6. Bond market volatility in Southeast Asia 
Appendix B. Origins of explanatory variables used in the empirical analysis

Table 7. Explanatory variables 
Appendix C. Sigma-convergence of significant regional variables corresponding to areas which have not experienced crisis (dependent variable 0)

Fig. 7. INTRTE (Mexican crisis)

Fig. 8. BUDG (Argentina crisis)

Fig. 9. LIQ (Argentina crisis)

Fig. 10. DEBT (Argentina crisis)

Fig. 11. CREDRISK (comparison Asia/Eastern Europe)

Fig. 12. LIQ (comparison Asia/Eastern Europe)

Fig. 13. DEBT (comparison Asia/Eastern Europe) 
Table 1. List of Mercosur countries hit by Latin American crises

\begin{tabular}{|c|c|c|c|}
\hline Countries & $\begin{array}{c}\text { Mexican } \\
\text { crisis }\end{array}$ & $\begin{array}{c}\text { Brazilian } \\
\text { crisis }\end{array}$ & $\begin{array}{c}\text { Argentina } \\
\text { crisis }\end{array}$ \\
\hline Argentina & $\mathbf{1}$ & $\mathbf{0}$ & $\mathbf{1}$ \\
\hline Bolivia & $\mathbf{0}$ & $\mathbf{0}$ & $\mathbf{0}$ \\
\hline Brazil & $\mathbf{1}$ & $\mathbf{1}$ & $\mathbf{0}$ \\
\hline Chile & $\mathbf{0}$ & $\mathbf{0}$ & $\mathbf{0}$ \\
\hline Mexico & $\mathbf{1}$ & $\mathbf{0}$ & $\mathbf{0}$ \\
\hline Paraguay & $\mathbf{0}$ & $\mathbf{1}$ & $\mathbf{1}$ \\
\hline Uruguay & $\mathbf{0}$ & $\mathbf{0}$ & $\mathbf{1}$ \\
\hline
\end{tabular}

Table 2. List of Asean countries hit by the Thai crisis Table 3. List of Cefta countries hit by the Turkish crisis

\begin{tabular}{|c|c|}
\hline Countries & $\begin{array}{c}\text { Asian } \\
\text { crisis }\end{array}$ \\
\hline Indonesia & $\mathbf{1}$ \\
\hline Korea & $\mathbf{1}$ \\
\hline Malaysia & $\mathbf{1}$ \\
\hline Philippines & $\mathbf{1}$ \\
\hline Singapore & $\mathbf{1}$ \\
\hline Thailand & $\mathbf{1}$ \\
\hline
\end{tabular}

\begin{tabular}{|c|c|}
\hline Countries & $\begin{array}{c}\text { Turkish } \\
\text { crisis }\end{array}$ \\
\hline Bulgaria & $\mathbf{0}$ \\
\hline $\begin{array}{c}\text { Czech } \\
\text { Republic }\end{array}$ & $\mathbf{0}$ \\
\hline Hungary & $\mathbf{0}$ \\
\hline Poland & $\mathbf{0}$ \\
\hline Slovakia & $\mathbf{0}$ \\
\hline Slovenia & $\mathbf{0}$ \\
\hline Turkey & $\mathbf{1}$ \\
\hline
\end{tabular}


Table 4. List of explanatory variables

\begin{tabular}{|c|c|c|c|}
\hline Variable & Definition & Expected sign & Role of the variable \\
\hline Inflation rates & $\begin{array}{l}\text { Rate of change in percent of } \\
\text { the consumer prices }\end{array}$ & $\begin{array}{l}\text { Inf }(+) \\
\text { Inf_rg }(+)\end{array}$ & $\begin{array}{l}\text { A low inflation differential shows a homogeneous preference in the economic policies of an area that can attract } \\
\text { investors and banks (Kindleberger (1986)). }\end{array}$ \\
\hline Interest rates & Monetary market rate & $\begin{array}{l}\text { Intrte }(+) \\
\text { Intrte_rg }(+)\end{array}$ & $\begin{array}{l}\text { This indicator shows the mobility of the capital between countries that helps to resorb the negative effects of an } \\
\text { asymmetric shock (Ingram (1969)). The weakness of this indicator points to a high degree of international integration. }\end{array}$ \\
\hline $\begin{array}{l}\text { Budgetary } \\
\text { policy }\end{array}$ & $\begin{array}{l}\text { Budgetary deficit in percent of } \\
\text { GDP }\end{array}$ & $\begin{array}{l}\text { Budg }(-) \\
\text { Budg_rg }(+)\end{array}$ & $\begin{array}{l}\text { According the Maastricht criteria (Pisani-Ferry (2002)), a convergence of the budgetary policies towards a common } \\
\text { reference is important for the sustainability of the Euro area. Both national taxes and international markets can finance } \\
\text { an overlarge budgetary deficit. This deficit may grow in the long run and raise the external debt. This instability may } \\
\text { then generate a loss in investors' confidence that withdraw their capital from the area (Moreno (1995)). }\end{array}$ \\
\hline Credit risk & $\begin{array}{l}\text { Ratio of private sector credits } \\
\text { to banking deposits }\end{array}$ & $\begin{array}{l}\text { Credrisk }(+) \\
\text { Credrisk_rg(+) }\end{array}$ & $\begin{array}{l}\text { In the third generation of crisis models, some authors (Chang and Velasco (2000), (2001), Mishkin (1999)) show } \\
\text { that the high vulnerability of countries to speculative attacks during the last decade was due to banking weakness. } \\
\text { So, the significant weight of the banking sector in emerging countries and the excessive risk-taking in this sector } \\
\text { have generated a credit "boom" just before recent financial crises. } \\
\text { A high level of this indicator reveals a large risk that can induce a loss in the confidence of international banks, which } \\
\text { are the main creditors of the commercial banks in emerging countries. }\end{array}$ \\
\hline External debt & $\begin{array}{l}\text { External debt in percent of } \\
\text { GDP }\end{array}$ & $\begin{array}{l}\text { Debt }(+) \\
\text { Debt_rg }(+)\end{array}$ & $\begin{array}{l}\text { Exchange rate literature has stressed the fact that the emerging countries that had a large external debt were hit by } \\
\text { financial crisis (Krugman (1999), Corsetti, Pesenti, Roubini (1998), (1999)). }\end{array}$ \\
\hline $\begin{array}{l}\text { Illiquidity } \\
\text { risk }\end{array}$ & $\begin{array}{l}\text { Ratio of short-term external } \\
\text { debt to international reserves }\end{array}$ & $\begin{array}{l}\operatorname{Liq}(+) \\
\operatorname{Liq}{ }_{-} r g(+)\end{array}$ & $\begin{array}{l}\text { According to economic literature (Furman and Stiglitz (1998)), just before the crisis countries experienced an important } \\
\text { risk of illiquidity, which was at the origin of the loss of investors' confidence. }\end{array}$ \\
\hline $\begin{array}{l}\text { Current } \\
\text { account } \\
\text { balance }\end{array}$ & $\begin{array}{l}\text { Current account deficit in } \\
\text { percent of GDP }\end{array}$ & $\begin{array}{l}C A(-) \\
C A+r g(+)\end{array}$ & $\begin{array}{l}\text { The current deficit shows the bad financial situation of a country compared with the rest of the world. It corresponds to } \\
\text { a need for capital. This situation can generate a decrease of international reserves and an increase of the external debt if } \\
\text { it is not reduced through long-term capital inflows. This can lead to an unsustainable risk. }\end{array}$ \\
\hline $\begin{array}{l}\text { Economic } \\
\text { integration }\end{array}$ & $\begin{array}{l}\text { Ratio of bilateral trade in the } \\
\text { same block weighted by the } \\
\text { importance of each country to } \\
\text { the amount of trade with the } \\
\text { rest of the world }\end{array}$ & $\operatorname{Int}(-/+)$ & $\begin{array}{l}\text { The aim here is to determine if regional economic integration can be a criterion for protection against crisis, as shown } \\
\text { by Frankel (1996), or if it generates contagion because of trade links. } \\
\text { The more important the ratio is, the higher the importance given to regional commercial partners will be. }\end{array}$ \\
\hline $\begin{array}{l}\text { Financial } \\
\text { integration }\end{array}$ & $\begin{array}{l}\text { Sum of the stock portfolio } \\
\text { equity and the stock of direct } \\
\text { investment assets and } \\
\text { liabilities to GDP }\end{array}$ & Fiint $(+)$ & $\begin{array}{l}\text { A volume based measure of international financial integration has been chosen from the global indicator and data } \\
\text { proposed by Lane and Milesi-Ferretti (2006). The emerging countries' rapid financial liberalisation and the large inflow } \\
\text { of volatile capital seem to have increased banks' illiquidity risks and their vulnerability to external shock and changes } \\
\text { in the expectations of international investors (Chang and Velasco (2000), Edwards (2000)). }\end{array}$ \\
\hline
\end{tabular}


Table 5

Results of the probit analysis with national indicators

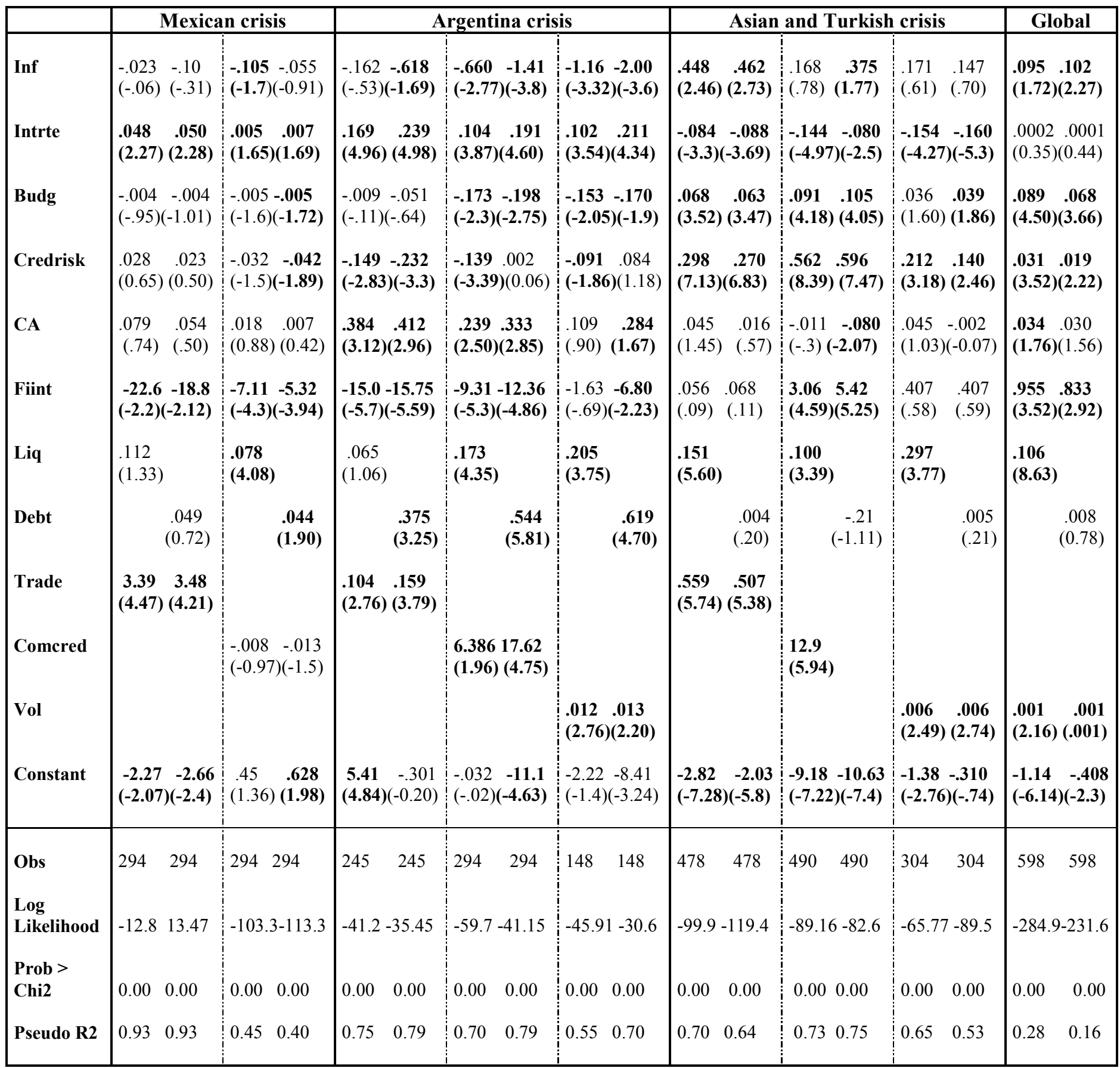

Values in brackets represent the $\mathrm{z}$ significance level of the coefficient. 
Table 6

Results of the probit analysis with regional indicators

\begin{tabular}{|c|c|c|c|c|c|c|c|c|}
\hline \multirow[b]{2}{*}{ Inf_Rg } & \multicolumn{2}{|c|}{ Mexican crisis } & \multicolumn{2}{|c|}{ Argentina crisis } & \multicolumn{2}{|c|}{$\begin{array}{c}\text { Asian and Turkish } \\
\text { crisis }\end{array}$} & \multicolumn{2}{|c|}{ Global } \\
\hline & $\begin{array}{l}.131 \\
(0.44)\end{array}$ & $\begin{array}{l}.027 \\
(0.10)\end{array}$ & $\begin{array}{l}.043 \\
(0.07)\end{array}$ & $\begin{array}{l}.882 \\
(1.55)\end{array}$ & $\begin{array}{l}2.23 \\
(2.29)\end{array}$ & $\begin{array}{c}1.50 \\
(2.54)\end{array}$ & $\begin{array}{l}.0005 \\
(0.01)\end{array}$ & $\begin{array}{l}.091 \\
(0.90)\end{array}$ \\
\hline Intrte_Rg & $\begin{array}{l}.053 \\
(1.76)\end{array}$ & $\begin{array}{c}.062 \\
(2.15)\end{array}$ & $\begin{array}{l}.0006 \\
(0.02)\end{array}$ & $\begin{array}{l}-.047 \\
(-1.54)\end{array}$ & $\begin{array}{l}-.652 \\
(-2.74)\end{array}$ & $\begin{array}{l}-.339 \\
(-2.50)\end{array}$ & $\begin{array}{l}.003 \\
(1.51)\end{array}$ & $\begin{array}{c}.002 \\
(0.88)\end{array}$ \\
\hline Budg_Rg & $\begin{array}{l}-.803 \\
(-1.53)\end{array}$ & $\begin{array}{c}2.15 \\
(-1.66)\end{array}$ & $\begin{array}{r}.353 \\
(1.90)\end{array}$ & $\begin{array}{c}.489 \\
(2.14)\end{array}$ & $\begin{array}{c}-.827 \\
(-3.77)\end{array}$ & $\begin{array}{c}-.431 \\
(-4.36)\end{array}$ & $\begin{array}{l}-.126 \\
(-2.13)\end{array}$ & $\begin{array}{l}-.100 \\
(-1.78)\end{array}$ \\
\hline Credrisk_Rg & $\begin{array}{l}-.017 \\
(-0.14)\end{array}$ & $\begin{array}{c}.018 \\
(0.16)\end{array}$ & $\begin{array}{c}-.077 \\
(-0.36)\end{array}$ & $\begin{array}{l}-.284 \\
(-1.27)\end{array}$ & & & $\begin{array}{l}.084 \\
(2.94)\end{array}$ & $\begin{array}{l}.087 \\
(3.19)\end{array}$ \\
\hline Ca_Rg & $\begin{array}{c}.200 \\
(0.80)\end{array}$ & $\begin{array}{c}.195 \\
(0.77)\end{array}$ & $\begin{array}{c}.157 \\
(1.13)\end{array}$ & $\begin{array}{l}.144 \\
(1.09)\end{array}$ & $\begin{array}{l}-.386 \\
(-1.94)\end{array}$ & $\begin{array}{c}-.165 \\
(-1.49)\end{array}$ & $\begin{array}{l}-.036 \\
(-1.09)\end{array}$ & $\begin{array}{c}-.041 \\
(-1.24)\end{array}$ \\
\hline Liq_Reg & $\begin{array}{c}.096 \\
(1.40)\end{array}$ & & $\begin{array}{l}.436 \\
(2.22)\end{array}$ & & $\begin{array}{l}.671 \\
(3.40)\end{array}$ & & $\begin{array}{l}.131 \\
(4.66)\end{array}$ & \\
\hline Debt_Rg & & $\begin{array}{c}.182 \\
(1.59)\end{array}$ & & $\begin{array}{l}.547 \\
(2.95)\end{array}$ & & $\begin{array}{l}.305 \\
(2.59)\end{array}$ & & $\begin{array}{l}.117 \\
(3.44)\end{array}$ \\
\hline Int-Reg & $\begin{array}{l}.812 \\
(2.63)\end{array}$ & $\begin{array}{l}.781 \\
(2.65)\end{array}$ & $\begin{array}{l}.161 \\
(0.48)\end{array}$ & $\begin{array}{l}1.02 \\
(3.82)\end{array}$ & $\begin{array}{l}-1.03 \\
(-1.18)\end{array}$ & $\begin{array}{l}-1.25 \\
(-1.59)\end{array}$ & $\begin{array}{c}-.241 \\
(-3.69)\end{array}$ & $\begin{array}{l}-.131 \\
(-2.08)\end{array}$ \\
\hline Vol & & & $\begin{array}{r}.017 \\
(3.82)\end{array}$ & $\begin{array}{l}.012 \\
(3.01)\end{array}$ & $\begin{array}{c}.006 \\
(1.61)\end{array}$ & $\begin{array}{c}.006 \\
(2.20)\end{array}$ & $\begin{array}{l}.008 \\
(5.69)\end{array}$ & $\begin{array}{l}.007 \\
(5.73)\end{array}$ \\
\hline Constant & $\begin{array}{c}-8.83 \\
(-2.94)\end{array}$ & $\begin{array}{l}-8.84 \\
(-3.13)\end{array}$ & $\begin{array}{c}-6.03 \\
(-3.14)\end{array}$ & $\begin{array}{c}-8.10 \\
(-3.45)\end{array}$ & $\begin{array}{l}5.19 \\
(2.35)\end{array}$ & $\begin{array}{l}3.93 \\
(2.30)\end{array}$ & $\begin{array}{l}-1.22 \\
(-3.71)\end{array}$ & $\begin{array}{c}-1.44 \\
(-3.68)\end{array}$ \\
\hline Obs & 98 & 98 & 98 & 98 & 92 & 92 & 190 & 287 \\
\hline Log Likelihood & -14.93 & -14.84 & -28.57 & -25.63 & -18.80 & -33.35 & -127.03 & -133.8 \\
\hline Prob $>$ Chi2 & 0.00 & 0.00 & 0.00 & 0.00 & 0.00 & 0.00 & 0.00 & 0.00 \\
\hline Pseudo R2 & 0.78 & 0.78 & 0.58 & 0.62 & 0.70 & 0.48 & 0.36 & 0.33 \\
\hline
\end{tabular}

Values in brackets represent the z significance level of the coefficient. 
Fig. 1. Stock market volatility in Latin America

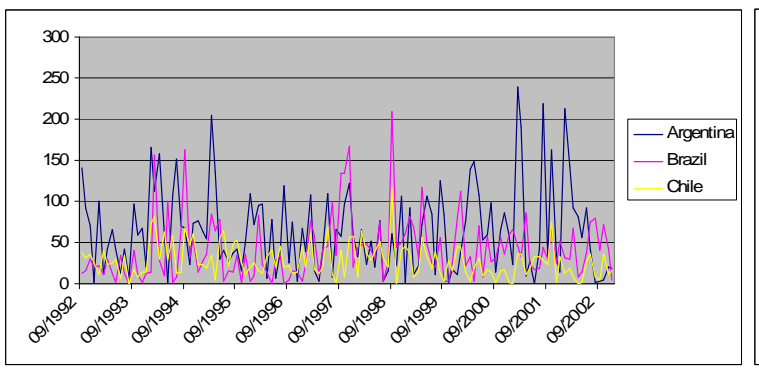

Fig. 2. Stock market volatility in Eastern Europe

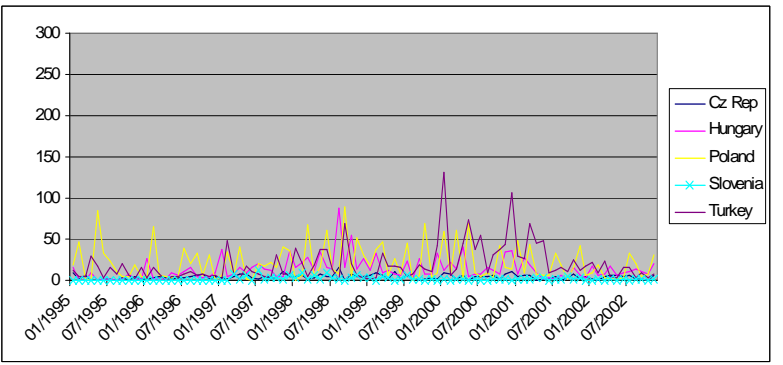

Fig. 3. Stock market volatility in Southeast Asia

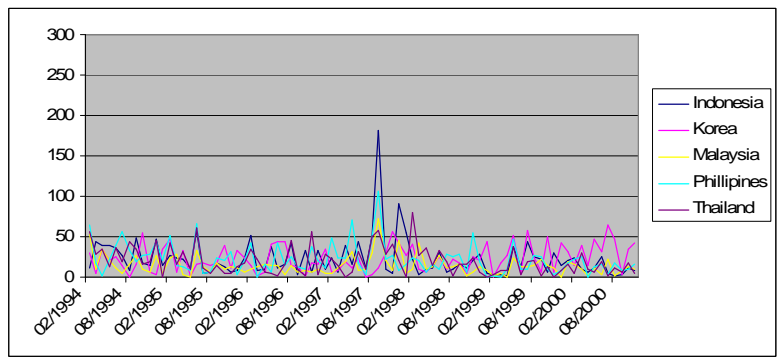

Fig. 4. Bond market volatility in Latin America

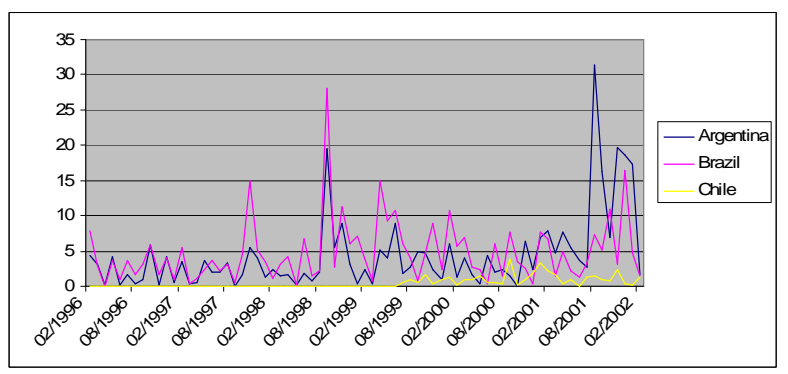

Fig. 5. Bond market volatility in Eastern Europe

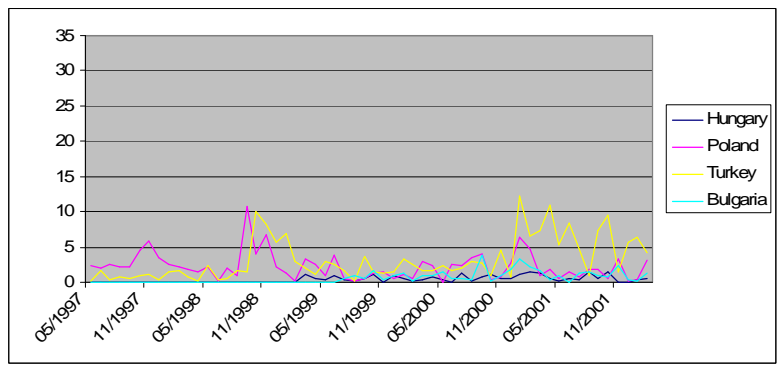

Fig. 6. Bond market volatility in Southeast Asia

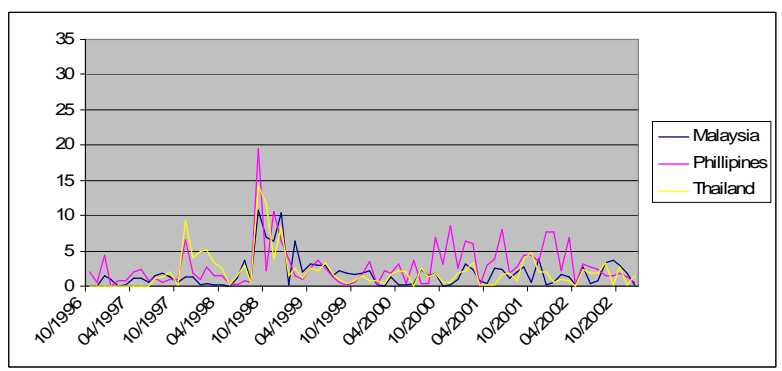


Table 7. Explanatory variables

\begin{tabular}{|c|c|}
\hline $\begin{array}{l}\text { Trade } \\
\text { Imports and Exports between countries, first country total } \\
\text { Imports and Exports (millions US Dollars) }\end{array}$ & DOTS \\
\hline $\begin{array}{l}\text { Comcred } \\
\text { Countries borrows to principal creditors of the area and } \\
\text { credits of international banks to countries (millions US } \\
\text { dollars) }\end{array}$ & BIS \\
\hline $\begin{array}{l}\text { Vol } \\
\text { Emerging countries stock exchange index (Standard and } \\
\text { Poors) }\end{array}$ & DATASTREAM (S\&P/IFCG) \\
\hline $\begin{array}{l}\text { INF } \\
\text { Consommation price index }\end{array}$ & IFS. Ligne 64.ZF \\
\hline $\begin{array}{l}\text { INTRTE } \\
\text { Monetary interest rate }\end{array}$ & IFS. Ligne 60B.ZF. \\
\hline $\begin{array}{l}\text { BUDG } \\
\text { Budgetary deficit/surplus (millions US Dollars) } \\
\text { Gross Domestic Product (millions US Dollars) }\end{array}$ & $\begin{array}{l}\text { IFS } \\
\text { Ligne 80.Z.F. } \\
\text { Ligne 99.B. }\end{array}$ \\
\hline $\begin{array}{l}\text { CREDRISK } \\
\text { Banking Deposits (millions US Dollars). } \\
\text { Credit to private sector (millions national currency). } \\
\text { Exchange rate national currency per US Dollar }\end{array}$ & $\begin{array}{l}\text { IFS } \\
\text { Ligne 7A.DZF } \\
\text { Ligne 52.DZF } \\
\text { Ligne ae }\end{array}$ \\
\hline $\begin{array}{l}\text { CA } \\
\text { Current deficit/surplus (millions of US Dollars) } \\
\text { Gross Domestic Product (millions US Dollars) }\end{array}$ & $\begin{array}{l}\text { IFS } \\
\text { Ligne 78ALDZF. } \\
\text { Ligne 99.B. }\end{array}$ \\
\hline $\begin{array}{l}\text { DEBT } \\
\text { External debt (millions US Dollars). } \\
\text { Gross Domestic Product (millions US Dollars) }\end{array}$ & $\begin{array}{l}\text { BIS-IMF-OECD-WB } \\
\text { (www.bis.org) } \\
\text { Ligne 99.B. }\end{array}$ \\
\hline $\begin{array}{l}\text { LIQ } \\
\text { Short term debt (millions US Dollars). } \\
\text { Total Reserves minus gold (millions US Dollars) }\end{array}$ & $\begin{array}{l}\text { WB-WDI } \\
\text { IFS 1.L.DZF }\end{array}$ \\
\hline $\begin{array}{l}\text { INT } \\
\text { Imports and exports between countries and Towards the } \\
\text { rest of } \\
\text { the world (millions US Dollars) }\end{array}$ & DOTS \\
\hline $\begin{array}{l}\text { FIINT } \\
\text { Stock of portfolio equity and stock of direct investment } \\
\text { assets } \\
\text { and liabilities (in US Dollars) }\end{array}$ & $\begin{array}{l}\text { P. Lane, G.M. Milesi-Ferretti (2006) } \\
\text { database }\end{array}$ \\
\hline
\end{tabular}



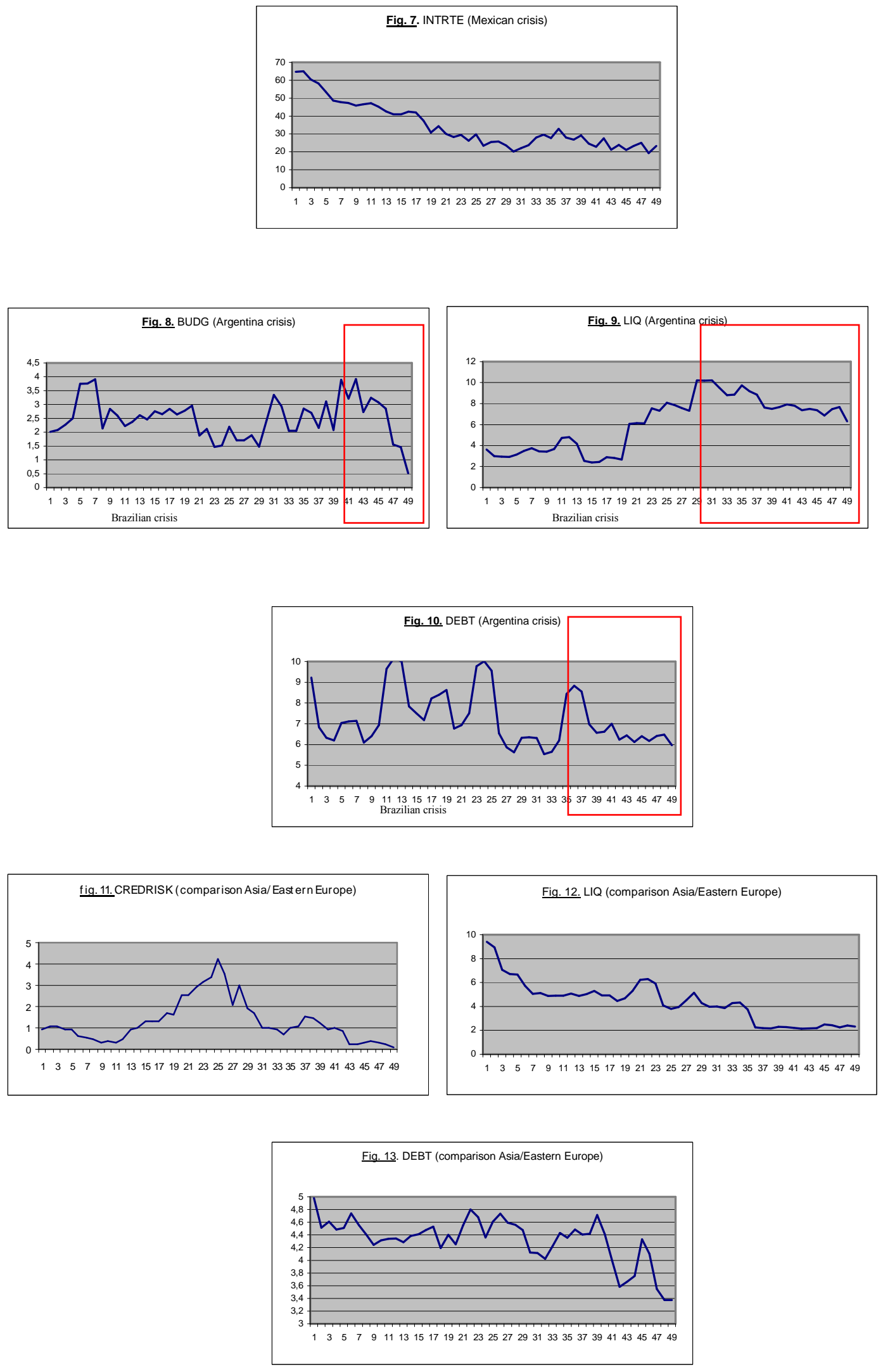